\title{
Hangi İslam?
}

\author{
Jacques Berque* \\ Çev. Bahaeddin YEDiYILDIZ**
}

\begin{abstract}
ÖZ
İslam terimi hem jeopolitik konuşlanmayı hem de en büyük üç tek Tanrılı dinin en gencinin sosyal ve manevi içeriklerini kapsar. Yedinci yüzyılın ilk yarısında Arabistan'da ortaya çıkan İslam, ihtida, kültürel cazibe ve fetih yoluyla yayıldı. Bazıları tarafindan hala bilinmiyor olsa da, günümüzde dünyanın en canlı sistemlerinden biridir. $\mathrm{Bu}$ makale, 20. yüzyılın ünlü Fransız sosyal bilimcisi Jacques Berque'in ölümünden bir hafta önce Avrupa ve Arap Dünyası ile İslâm ve Batı ilişkileri hakkında yapmış olduğu tarihî ve sosyolojik bir tahlildir. Berque burada yoğun ve özlü bir anlatımla İslam'ın coğrafî ve beşerî konumuna, kültürel farklılıklarına, diğer bir ifadeyle bu köklü medeniyetin çağımızda farklılaşmı̧s uzantılarına dikkat çekiyor. İslam ülkeleri arasında gerçekleştirilen uluslararası toplantılarda, İslam medeniyetinin temel sorunlarının tartışılmasından daha çok yerel ve geçici bazı meseleler üzerinde durulmakla yetinildiğini vurgulayan Berque, çağımızda İslam'ın asıl meselelerini küresel kapsamda ele alıyor. Ona göre, Ortaçağda İslam Batı tarafindan, mesela bir Pierre Abélard (1079-1142), bir Ramon Lull (1235-1315) tarafindan daha iyi anlaşılmıştı. Batı'nın İslam ve Çin gibi oluşumlara karşı tutumu,
\end{abstract}

\footnotetext{
J. Berque'in (1910-1995) bu yazısının Fransızca orijinali ilk defa Le Temps stratégiquéte (No 64, Haziran 1995) yayınlanmıştır. Berque, gençliğinde Cezayir'in Hodna adlı bir yayla bölgesinde bir kabilenin içinde yaşayarak onlardan Arapçayı öğrendi ve Fes'in Karaviyyin Üniversitesi Şeyhleri ile birlikte Müslüman hukukunu inceledi. Daha sonra, çeyrek yüzyıl boyunca, Sorbon’da ve Collège de France'da Çağdaş İslam'ın Toplumsal Tarihi Kürsüsü 'nün sorumlusu ve Unesco uzmanı olarak görev yaptı. Otuzdan fazla sosyal tarih eserinin yazarıdır. Bunlar arasında, Dünden Yarına Araplar (Les Arabes d'bier à demain, Paris, Seuil, 1960), Mağrip’in İ́cbölgesi (L'Intérieur du Maghreb, Paris, Gallimard, 1978) ve Dünya Vaktinde İslam (L'Islam au temps du monde, Paris, Sindbad, 1984) gibi kitapları vardır. 1981'den itibaren ölümüne kadar Landes'teki aile köyünde emekli olarak yaşayan Jacques Berque, Kur'an'ın yeni bir çevirisini (Traduction du Coran, Paris, Sindbad, 1991), bir cilt hâlinde İki Kıyının Hatıraları (Mémoires des deux rives, Paris, Seuil, 1989) adıyla anılarını ve Bir Gelecek Kalır (Il reste un avenir, Paris, Arléa, 1993) adıyla daha genel bir deneme yayınladı. Berque hakkında geniş bilgi için bkz. Neslihan Er, “Berque, Jacques”, DİA, c. Ek 1, 2016, s. 188-190. Yanında muhtelif ülkelerden birçok kişi doktora yapmıştır. Bu satırların yazarı da bunlardan biridir (BY).

** Prof. Dr. Hacettepe Üniversitesi Edebiyat Fakültesi Tarih Bölümü’nden emekli.

E-posta: bahaeddinyediyildiz@gmail.com, ORCID: 0000-0001-9838-4222,DOI: 10.32704/erdem.838785 Makale Gönderim Tarihi: 27.12.2019* Makale Kabul Tarihi: 15.12.2020 * (Çeviri Mk.)
} 
Sanayi Devrimi'nden sonra değişti. Kibir ve egemenlik mantığı hâkim oldu. Emperyalizm ya da "sanayi devriminin genişlemesi", halklar ve kültürler arasındaki değişim mekanizmasını bozdu. İslam, iki veya üç asırdan bu yana, geçmişte kendisinin de kullandığı Batı rasyonalitesini işletmeyi sürdüremedi. İbn Rüşt ya da İbn Haldun'un çok verimli düşünceleri takipçilerini bulamadı. Bu büyük medeniyet mekanik performanslardan mahrum kaldı. "Takip hastalığına” tutuldu, taklitten başı döndü. Batı ile ilişkileri, "burukluk ve ötekilik" temeli üzerine oturdu. Batı bugün İslam'a tamamen olumsuz yaklaşıyor. Japonya'yı ayıplamıyor, ondan korkuyor. Ona göre, Çin kullanılacak harika bir müşteri... Hindistan'ın "metafizik eğilimi” bu devi "zararsız" kılıyor. Müslüman’a gelince, o “ebedi bir Sarazen'dir. En kötü bir modernlikle daha tehlikeli olabilir. Batı, İslam'ı üç konuda suçluyor: "Bazen terörizme varan bir saldırganlık; din görevlisini siyasette kullanma eğilimi; İnsan haklarına saygı konusunda isteksizlik... Bugün kadın hakları bunun en kesin ölçütüdür”. Berque, bunların sebeplerini anlatarak cevaplarını veriyor. İslam'da bu sorunları gözlemlemenin, Batı tarihinin yıkımlarını unutturamayacağını belirtiyor ve "örosantrizmden/Avrupa merkezciliğinden” sakınılmasını tavsiye ediyor. Berque'e göre, İslam, maneviyatının bir kısmını kaybetmeye başlamıştır. Müslümanların çoğu, İslam’ı yabanc1 kumpaslara, rejimlerin başarısızlığına ve insanların kötülüğüne karşı bir sığınak olarak görüyor. Bu rol, manevî rolün önüne geçmiştir. Demokrasi mahkûm edilmiştir. Bazı grupların bu tutumu, Müslüman toplumların tümünün bağnazlık ve hoşgörüsüzlükle suçlanmalarına sebep olmuştur. Bu toptanc1 suçlamalar tamamen «haksız"dır. Ancak bugünün İslam’1 kitleleri tatmin etmiyor. Özgünlüğünü koruyan ve dünyanın gidişatına ayak uyduran bir "gelişme İslam'ı", dinamik bir İslam inşa etmek gerekiyor.

Anahtar Kelimeler: Din, kültür, medeniyet, İslam, Avrupa, sömürgecilik, çağdaşlaşma. 


\title{
Which Islam?
}

\begin{abstract}
The term Islam involves both geopolitical deployment and the social and moral content of the youngest monotheistic religion. Having emerged in the first half of the seventh century in Arabia, Islam spread through conversion, cultural attraction and conquests. It is still one of the liveliest systems of the world though that is not recognized by many. This article is a historical and sociological analysis made by Jacques Berque -renowned French social scientist of the twentieth century- one week before his death on European and Arab worlds; and the relations between Islam and the West. Berque draws attention to geographic and human position and cultural differences of Islam -in other words, to differentiated extents of that rooted civilization- with a compact and concise expression. $\mathrm{He}$ emphasizes that the international meetings between the Islamic countries cover local and temporal affairs rather than discussing the main problems of the Islamic Civilization; and he examines the essential issues of Islam at our age within a global content. For him, Islam was better understood in West in the Middle Ages, for instance, by Pierre Abélard (1079-1142) and Ramon Lull (1235-1315). The attitude of the West against Islam and China changed after the Industrial Revolution. Conceit and conception of supremacy prevailed. The imperialism or "spreading of the Industrial Revolution" damaged the exchange mechanism among the communities and cultures. For two or three centuries, Islam has not maintained working the Western rationality, which it actually had used in past. Productive ideas of Averroes or Ibn Khaldoun could not find followers. Such a great civilization lacked mechanical performances. It fell into the "disease of imitation". Its relations with the West were set on the base of "acridty and otherness." Today the West approaches to Islam in a completely negative way. It does not blame Japan, and is afraid of it. China is a great and useful client. "Metaphysical inclination" of India renders it harmless. However, when it is about the Muslims, they are "perpetual Saracens". They could be more dangerous with the worst modernism. The West accuses Islam of three matters: "Aggression that sometimes leads to terrorism; tendency to use religious officials in politics; reluctance for respect to civil rights. The issue of rights of the women is a definite measure of it." Berque explains the reasons of those and answers them. He states that observing those problems in Islam would not efface the destruction of the Western history and suggests avoiding "Eurocentrism". For Berque, Islam began to lose a part of its morality. Most of the Muslims see Islam as a shelter against foreign conspiracies, failures of regimes and evil of the people. This role prevents its moral role. Democracy is condemned. This kind of attitude of certain groups resulted in blaming all Muslim communities for bigotry and intolerance. These accusations are completely "unfair". But today's Islam do not satisfy masses. A "development Islam" and a dynamic Islam that maintains its genuineness and keeps pace with the state of affairs of the World needs to be built.
\end{abstract}

Keywords: Religion, culture, civilization, Islam, Europe, colonialism, modernisation. 


\section{İslam, Üç Büyük Tek Tanrılı Dinin En Gencidir}

\section{I.DURUM. Aralık 1994 ortalarında İslam Konferansı Teşkilatı Kazablanka'da} topland. Bu toplantıya Müslüman olmakla övünen elliye yakın millet veya hareket katılmıştı. Bu bayrağı benimseyen etkileyici çeşitlilik, toplumları, imgeleri ve gelişmenin en farklı evrelerini yüz yüze getiriyordu. Bu toplant1da, Afrika savanasının ${ }^{1}$ çağrıştırdıkları Orta Asya steplerinin hatırlattıkları ile, Malezyalılara ait dalyanların çağrıştırdıkları ise Sahra kervanlarınınki ile buluşuyordu. Eski Fas monarşisi ile Moros denen Filipinli Müslümanların başkaldırıları yan yanaydı orada. Kazanlı bir Tatar, Şamlı bir bilginden el yazmalarını soruşturuyordu. Dünya haritası üzerindeki bu beşerî gökkuşağ1, kime sorulursa sorulsun, Arap dikdörtgeninin beriki ve öteki yanında tamamen karasal bir destek gibi görülür. İşte burası on dört asırdan beri Kur'an̂े vahyin merkezidir. Arap, aslında Kur'an'ı kendi tekeli altına almak istiyordu: Bizzat o, bunu onaylıyor. Bu, Arap için bir nevi doğuştan hak ${ }^{2}$ demekti. Louis Massignon'un ifadesiyle, Arap İslam'ın ekseni içinde olduğu kadar İslam da Arap'ın ekseni içindedir.

\section{Dünya Haritası Üzerinde Beşerî Gökkuşağı, Yazılı ve Yazılı Olmayan Yüksek Medeniyet}

Ve yine, Kazablanka'da bu karışık toplantıda, birçok yerel dil birbirine karış1yordu. Bunlardan bazıları, herkes tarafindan tanınan bir klasisizmin ayrıcalığını Arapça ile paylaşıyordu: Sadece şâheserlerle yüklü dillerden bahsedilecek olursa, Farsça ve Türkçe böyledir. Fakat sadece sığ bir bilgiçlik taslama, bu akademik panteona bağlı kalabilirdi. Konferans bünyesinde, zengin halk kültürlerinin, yazı11-olmayan köklü geleneklerin temsilcileri de canlılık gösteriyordu. Ayrıca, bu şölenlere davet edilen Müslüman Afrika da, sefaletlerinin tanıklığı ile yağmalanmış hazinelerinin izlerini taşımıştı buraya.

Köktencilik ya da köktendincilik (entegrizm) veya İslamcıllk, behemehâl Nil Afrika'sından ve daha kesin bir ifadeyle Sudan'dan Dr. Hasan et-Turabi'nin ${ }^{3}$

Savana, Ekvator kuşağında otsu bitkilerle kaplı çayırlara verilen isimdir (BY).

2 Özgün metinde "droit d'ainesse" kavramı kullanılmıştır. Batılılar buna "droit de primogenitura" da demektedirler. Osmanlı Türkçesinde "hakk-1 bekûriyet" veya "hakk-1 tekaddüm" denilmektedir. En büyük çocuğun diğerlerinden daha çok mirasa sahip olması hakkı demektir. Bir zamanlar İngiltere'de büyük oğul mirasın iki katını alıyordu. Doğuştan sahip olunan hak, ait olduğumuz aile ya da ülke sebebiyle doğuştan sahip olduğumuza inandığımız hak anlamına da gelmektedir. Hürriyet her insanın doğuştan tabi hakkıdır. "Bedava kamu eğitimi her Amerikalı çocuğun doğuştan hakkıdır". Bu örneklerde olduğu gibi, Berque de, Arapların Kur 'an'ı doğuştan kendilerinin hakkı olduğuna inandıklarını belirtmek istemektedirler (BY).

3 Hasan el-Turabi (1922- ), Fransa'da eğitim görmüş bir hukukçudur. 1989 darbesinden bu yana Sudan'da iktidardaki İslami Ulusal Cephe’ye liderlik ediyor. İslamcı güçlerin uluslararası akı1 
tezleriyle en kışkırtıcı kanıtlamaları ileri sürüyordu. Yı1lardan beri günün konusu olan ve konferansta aniden ortaya çıkan Turabi, oturum başkanı olan Fas kralı tarafından açılış konuşmasından sonra oradan uzaklaştırılmıştı. II. Hasan şöyle diyordu: İslam, hoşgörü ve orta yol gelenekleri adına bu görüşleri reddeder. Gelecekle ilgili ne hoş tartışma!

Ancak tartışma gerçekleşmedi. Konferans, benzer uluslararası toplantılarda olduğu gibi, delegeler arasındaki çatışmaları çözmek ve temel sorunları ele almaksızın yerel ve geçici durumları görüşmekle sınırlı kaldı. İşte bu makale, söz konusu temel sorunları ele alma cesaretini gösterecektir.

En küçük duygusallığa kapılmaksızın, sanayi devriminin gezegen üzerinde eşit olmayan ilişkiler içinde yayıldığını görecek olduğumuz her yerde emperyalizm, sürekli olarak halklar arasındaki ve kültürler arasındaki mübadeleyi ifsat edecektir. Doğrudan bu tahribata maruz kalan İslam, uzun süre teknolojik ilerleme tarafindan terk edilmiş ve bundan dolayı yabancı müdahalesine teslim olmuş sektörlere dayanarak hüküm sürmüş olacaktır. İslam, iki ya da üç yüzyıldan beri, tarihsel olarak bu ilerleyişe bağlı Batı akılcılığının yollarını takip etmemiştir. Eski Yunanlılar gibi, Mağrip, Ortadoğu, İran ve Müslüman Hindistan mekanik başarılardan yoksun büyük medeniyetler geliştirmişlerdi. Bu halklarda, maddi gecikme, iş işten geçtikten uzun zaman sonra çözümlenecek olan, -hayranlık ve isyanla karış1k- bir aşağ 11 lk kompleksi oluşturdu. Tamamen ortadan kaybolduğu söylenemez, kaldı ki onun doğurduğu nesnel ilişkiler de devam edip gitmektedir.

\section{Fakat Medeniyet Teknolojik Başarılara Nüfuz Etmekte Gecikmiştir}

(Uygun yeni bir sözcük kullanmak gerekirse) üç-kara-kıtası (tricontinentale) kültürleri, tüm sosyal gövdenin değer kaybına mümasil bir kayba maruz kalmış olacaklardır. Müessiriyetten, makinaların ve kavramların etkililiğinden uzaklaştırılmış olan bu kültürler, klasizmlerinin kalıntıları ve tarihin itici güçlerinin onlara sunduğu halk-bilimsel yükümlülük arasında gerilmektedir. Avrupa modelinin izdüşümü, eskiden başarılı veya yaratıcı kültürleri bir bağımlılık içine itiyordu böylece. Öyle bir bağımlılık ki, bu kültürlerin savunma hamlelerinin, kimi zaman enerjik olmaları için, gelişme seviyesini yakalama çabasının acımasız yasasına ve aynı zamanda taklit sersemliğine takılmamaları gerekiyordu. Bu durum, söz konusu halkların siyasi hamlelerinin bu sü-

hocalığı rolünün kendisine verilmesini arzu etmektedir ve Arap-İslam Popüler Komisyonu'nu [Commission populaire arabo-islamique (CPAI)] canlı tutmaya çalışmaktadır. [Hasan el-Turabî 2016 yılında vefat etmiştir (BY)]. 
reci tersine döndürmesine kadar böyleydi. İkinci Dünya Savaşı sonrasından itibaren büyüyen bir güç sayesinde, pek çoğu İslami nitelikte olduklarını iddia eden yeni uluslar, eğitim ve yeniden yapilanma konusunda muazzam bir işe koyuldular ki, bu işin henüz tamamlandığı söylenemez.

Bir inanç ve manevi bir miras olarak İslam, bu değişkenliklerden diğer tektanricilıklara nazaran olumsuz anlamda daha fazla etkilenmek zorunda kalmamıştır. İslam’ın tabiatçı alakaları, Hıristiyanlıkta lütuf/inayet ile doğayı karşı karşıya getiren taban/asl ikiciliğinden bile kendisini koruyordu. Altın çağları boyunca o, Helenik physis [tabiat] geleneğini benimsemiş ve zenginleştirmemiş miydi? Teorik olarak hiçbir şey onu maddi ilerleme arayış1 içinde rahatsız etmedi. Buna mukabil, onun zayıllığı, modern zamanların istilacı dünyeviliğinden (sécularité) kaynaklanıyordu. Bu dünyevilik, İslam Yasası'nın manevi ve dünyevi arasında kurduğu bölünmezliğe ya da daha çok amaç-birliğine meydan okuyordu.

\section{Bu, Batı İle Karşılıklı Anlayış Mı? Hayır: Burukluk Ve Ötekilik}

Bu zorluğu biz, İslam'ın öğretisinde olduğu kadar davranışlarında da görüyoruz. Hayat ve fikirler kadrosunun büyüyen adaptasyonu/uyarlaması, bugün bile, İslam üzerinde pekâlâ etkili olabilir. Başkası ya da sadece komşularıyla olan iş ilişkileri, İslam için çözmesi gereken yeni sorunlar yaratmaktadır. Nihayet, çalı̧̧anlarından yüz binlercesinin ve eğitimli gençliğinin bir kısmının yurdu terk etmesi, ülkelerinde, farklı düzeylerde ve farklı biçimlerde kültürleşme/akkültürasyon fenomenleri/görüngüleri meydana getirmektedir. Bununla birlikte, şurası açıktır ki, bugün sistemler arasında, kültürler ve halklar arası anlayıştan daha çok biri birlerine duydukları burukluk ve ahenkten daha çok ötekilik söz konusudur.

II. İÇ-DÜNYALAR. İşte size tamamen birlikçi bir sistem... Bu sistem, insanın Tanrı tarafından yaratılması düşüncesine ve cesaretle insanoğlunun kozmik/evren ile ilgili bağlantıları diye adlandıracağım şeye dayanır. Doğalcılık/Natüralizm, bizim için anlaşılması güç bir biçimde aşkınlık fikriyle birleşir; hâlbuki biz, bu kavramları taban tabana zit olarak değerlendirmeye alı̧̧ı̧ıızdır. Simone Weil, “doğal” bir Tanrı olması muhtemel kitabî Tanrı ile Hristiyanların -Doğa-Üstünde kendini yücelten tek-tanrısı arasındaki zıtlığa dikkat çekmedi mi? Bu, aksine, İslam’a özgü Tanrı düşüncesinin anlaşılmasına yardımcı olabilir. Mamafih, Müslümanlar tanrılarını öteki iki tektanrıcıların taptıkları aynı Tanrı olarak kabul etmektedirler. "Bizim Tanrımız muhakkak sizinkiyle birdir” (Kuran XXIX, 46). 
Sonsuz bir gücün Tanrısı; eğer hürriyetimizi -bütün sorumluluklarıla baş başa bırakmasayd1- bu hürriyeti yok edebilirdi... Elbette, İslam mütefekkirleri, H1ristiyanlığın düşünürleri gibi, zor olan kader/alınyazısı tartısmasını $\imath^{4}$ gündeme getireceklerdi. Ancak onlar, kaderi -kendilerine isnat edildiği biçimiyle- fatalizm/kadercilik anlamı içinde değil, fakat özgürlük anlamı içinde çözmektedirler ${ }^{5}$. Şuna benzer birçok özdeyiş vardır: "Utanmazsan dilediğini yap” (Hadis). [Hadisler, Allah'ın elçisi Muhammed'in davranışının ve söyleşilerinin ayrıntılarıla ilgili kısa hikâyelerdir; hadislerin toplamı, Sünneti, Geleneği oluşturur.] Bir yorumcu, "bütün İslam’n etrafinda döndüğü eksen”, işte budur diyor. İslam, $y u s r^{6} /$ kolaylı dinidir, "özgür hareket”tir ("libre cours"). Büyük insan İkbal", sistemi nitelendirmek için Immediacy ${ }^{8}$ and wholeness ${ }^{9}$ diyordu. Eğer kelime türetme cesareti gösterecek olursak, bu iki terim Fransızcaya «immédiateté» ${ }^{10}$ (bilinçlilik, sezgi) ve «globalité» ${ }^{11}$ (bütünlük) olarak çevrilebilir.

Peki, bu yıllık oruç, kadının eve kapatılması, kutsal Savaş, başörtüsü dini, onun bizi sorguya çekmek için takındığı ciddî ya da mağrur çehreler, İslam-

$4 \quad$ Hıristiyanlıkta lütuf/inayet ve doğanın karşıtlığı: Lütuf, yani İnsanı Tanrı'nın iradesini gerçekleştirmeye ve kurtuluşa ermeye muktedir kılan doğaüstü yardım, insanın doğal davranışı ile çelişir. Dinbilimi, bir taraftan, manevi bir cevher/töz, ayinlerle insan tabiatına sinmiş ilahî bir güç olarak anlaşılan lütuf ile, diğer taraftan, insanın doğası, özgürlüğü ve karar verme gücü arasındaki bağlantıyı göstermeyi amaçlamaktadır. Bu zor tema üzerindeki bölünmelerden yüzyıllar sonra, ekümenizm/ekümeniklik bu konuda belirli bir fikir birliği oluşturmaya izin verecektir.

5 Alınyazısı/kader tartışması: Alınyazısı, teolojik/tanrıbilimsel bir doktrindir. Buna göre, Tanrı insanın kurtuluşuna bizzat kendisi karar vermektedir. Bu, aynı zamanda, ezelden beri, insanlığın kaderini ve dünyanın geleceğini belirlediği zamandaki Tanrı'yı tahayyül ettirecek olan niyettir de... Kur'an, sürekli olarak her şeyi yaratmış ve kararını vermiş olan "ilahi irade"den bahsetmektedir. Leibniz bu konuda şöyle diyordu: "Her şey şüphesiz belirlenmiştir, fakat öngörülmüş ve karara bağlanmış şeyin nasıl ve ne olduğunu bilmediğimizden, Tanrı'nın bize vermiş olduğu aklı kullanarak ve bize tavsiye ettiği kurallara uyarak görevimizi yapmalıyız". İslam'da, insan özgürlüğü ile eylemlerinin önceden belirlenmiş olması arasındaki bariz çelişki, kaderiye (özgür irade taraftarları) ile cebriyeyi ("bu yazılmıştır" veya mektub taraftarlarını) karşı karşıya getiren sayısız tartışmaların konusu olmuştur. Sünni ortodoksi bu iki karşıt eğilim arasında bir denge arayışı içinde oldu.

6 Yazar, metinde yusr kelimesini özgün haliyle kullanmıştır (BY).

7 Muhammed İkbal (1876-1938): Hintli şair ve filozof, şu an Pakistanlı. Onun dinamik düşüncesi, Kur'anî miras ile Batı'nın katkısı arasında bir sentez aradı. Urduca, Farsça ve İngilizce şiirleri olduğu kadar felsefi eserleri, Pakistan fikrinin temelini oluşturuyor (Ben-olmayanların Strlarl; Musa'nın Kılıcl; Doğu'nun Mesajl; Sonsuzluk Kitabl). The reconstruction of religious thought of Islam (İslam dini düşüncesinin yeniden inşası,1934) adlı bilgece eserinde, kendine has fikirleriyle Hindistanlı müceddid Ahmed Sirr Hindi'nin (1562-1620), Nietzsche'nin ve Bergson'un ilhamlarını özgün bir terkibe kavuşturdu.

8 Bu İngilizce kelimenin Zargan'daki karşılıkları şudur: 1.ânîlik, (zamanca) yakınlık, gecikmesizlik, ivedilik, beklemezlik, ânî zuhur, aracısızlık, doğrudan doğruya... Mevcut olma/vuku bulma. 2 . Fel. (a) bilinç(lilik): aracısız olarak (hafıza ve muhakemeye başvurmadan) edinilen bilgi, (b) sezgi: deneye veya usa vurmadan doğrudan doğruya bir şeyi biliverme (BY).

9 Tümlük, bütünlük, tamlık, noksansızlık (Zargan) (BY).

10 O anda oluş. Vasıtasızlık, dolaysızlık. Aciliyet (BY).

11 Küresellik (BY). 
cıların konuşmalarında gösterdiği bu saldırgan sertlik, sırf içimizde taşıdığımız doğru içgüdümüzden mi ileri gelmektedirler? İslam, hayatın sevinçleriyle ödüllendirilmiş bir Savoyard Vicar' $1 n^{12}$ hamlesi mi olacaktır? Şamlı hukukçu ve hadisçi Nevevi (1233-1277), şöyle diyordu: Birr ${ }^{13}$ ya da "erdem”, “yaratılışın güzelliği”” ne, büsnül-Halk'a: “davranışın kolaylığı, yüzün tatlılı̆̆ı, dilin nezaketi” ne indirgenmiştir. Şaşkınlığımızı itiraf edelim.

Skolastiklerimiz ${ }^{14}$, bu İslam'ı bizden daha iyi anlamış gözüküyor; onlar, Abelard ve Ramon Llull gibi ünlü isimlerin imzasını taşıyan diyaloglarda Müslüman muhataptan eskiçağ felsefesinin şampiyonu yapıyorlardı. Zaten bu filozoflar, bir Kindi ${ }^{15}$, bir Farabi ${ }^{16}$, bir Avicenne (İbn Sina) ${ }^{17}$ ve nihayet bir

12 Savoyard Vicar Jean-Jacques Rousseau'nun bir metnidir. Bu metnin tam adı, Vicaire Savoyard'in Imanının Açılanması (La profession de foi du Vicaire Savoyard)'dır; Emile' in (1762) bir parçasını teşkil etmektedir. Bir rahiple Emile'in gelecekteki özel hocası arasındaki bir diyalog, Rousseau'ya "asıl tapınması kalbinki olan” doğal bir dinin ilkesini açıklama imkânı vermektedir. Vicar, yaratıcı, ebedi, zeki, iyi ve adaletli bir tanrının varlığını istidlal etmek/çıkarımda bulunmak için evrenin hissedilebilir bir düzeninin apaçıklığına ve içsel bir duyguya dayanır. Bu ateşli metin çağı üzerinde muazzam bir tesir yaratmıştır.

13 Yazar, metninde Birr kelimesini özgün haliyle kullanmıştır (BY).

14 Skolastik felsefe: 13. yüzyıldan itibaren, özellikle teolojide, Orta Çağ’ın değeri olarak düşünce ve öğretim rejimi olan Skolastik, lectio, questio ve disputatio ile nitelendiriliyordu: Lectio, dini, felsefi ya da bilimsel doğanın eserlerini anlatmaya yönelik okumalar/yorumlar; questio, titiz bir şemaya göre teolojinin ve felsefenin problemlerini çözmek gayesiyle hoca tarafından sorulmuş olan sorular; ve disputatio ise, hoca ve ögrenciler arasında aleni tartışma demektir. Bu yöntem, dil sanatlarının, özellikle dilbilgisi ve diyalektiğin gelişmesine imkân sağlamıştır. Ünlü skolastik ustaları arasında şunlar zikredilebilir:

- Pierre Abelard (1079-1142): Skolastik teoloji ve mantık öğreten Abelard, Notre-Dame de Paris Katedrali'nin Piskoposluk Meclisi üyesidir. Heloise tarafından sevildi ve onunla gizlice evlendi. Doktrin ile ilgili sert muhalefetlerle karşı karşıya kaldı. Heloise'in dayısı -Piskoposluk Meclisi Üyesi- Fulbert'in kinleri de muhaliflerin iddialarını destekledi ve onu hadım ettirdi. Abelard, St. Bernard'ın kışkırttığı yeni bir kınamaya daha maruz kaldı. Paraclet manastırını kurdu ve Cluny'de öldü.

- Ramon Llull (1235-1315), ilahiyatçı, şair ve Katalan simyacı. Hayatı ve eserleri Hristiyanlığı yayma arzusunun egemenliği altındaydı: İbn Rüşd'ün doktrinlerine karşı çıktı, kendini üniversitelerde Arapça ve İbranice öğretmeye adadı ve Müslümanları Hristiyanlaştırmak için Kuzey Afrika'ya birçok yolculuk yaptı. Muhtemelen taşlanarak orada öldüğüne inanılıyor. Ramon Llull Katalan'a edebi saygınlık kazandırdı.

15 Kindi (796-873): En eski Arap filozofu olarak şöhret bulmuş olan felsefeci Ebu Yusuf ibn İshak el-Kindi, Yunan filozoflarını çevirilerinden biliyordu. Felsefe ve ilahi vahiy arasında bir karşıtlık görmüyordu. Orta Çă̆'da Latince'ye çevrilen birçok bilim eserinin (De quinque essentiis; De intellectu; Sur la philosophie première) ve müzik sanatıyla ilgili yedi kitabın yazarıdır.

16 Fârâbi (870-950): Batı Türkistanlı Filozof, Ebu Nasr Muhammed el Fârâbi, Bağdat ve Halep〉te yaşadı. Önemli bir Aristoteles uzmanı ve yorumcusu, Eflatunıun hayranı... Bu iki filozofun felsefelerini uzlaştırmayı denedi. Şu eserlerin yazarıdır: İki bilgenin, Eflatun ve Aristoteles`in görüşleri arasındaki uzlaşma; Erdemli Şehrin İlkeleri Kitabı; Siyasi anayasanın kitabı. Farabi’nin kozmolojisi, bilgelerin ve peygamberlerin idrakini, ilahi bir kaynaktan çıkan, evrenin basamaklı düzeni ile ilişkilendirir. Onun öğretisi, İbn Sina ve İbn Rüşd'ü etkileyecektir.

17 İbn Sina (980-1037): İran kökenli bir hekim ve filozof olan Ebu Ali Hüseyin İbn Abdallah ibn Sina, Batı'da Avicenna olarak bilinir. Avrupa'da uzun zaman tıp araştırmalarının temelini teşkil eden bir tıp Kanonu'nun yazarıdır. Arapça ve Farsça felsefi ve tasavvufî eserler yazdı. Bunların 
Averroès (İbn Rüşd) ${ }^{18}$ olarak nitelendiriliyorlardı. Bu sonuncusu, yönetimde yüksek bir İslam görevlisinin sorumluluklarını da yerine getiriyordu ${ }^{19}$.

Natüralizm/doğalc1lık -veya istenirse İslam imanının (credo) nesnelliği-, aslında, bir evren kavrayışına dayanır; insanoğluna özgü bir aklîlik de kaynağını burada bulur. Fitra denen bu "asal doğa"da, "temel bağlll1k" (ikblâc), ilk sebep ve kozmik ereklilik birbirine karışır. Burada, İslam, ana-kalıbı (fitrat) görür ki, “Tanrı insanları bu ana-kalıp üzerine kurmuştur, Tanrı'nın yaratmasının yerine geçebilecek hiçbir imkân yoktur” (Kur'an, XXX, 30).

Kur'an nedir? Bir, bilemedin iki nesilden bu yana, Kur'an'ın incelenmesi eğitimin esas ağırlığını teşkil ediyordu. Bu konuda, Mısırlı büyük yazar Taha Hüseyin'in Günler Kitabinda (1929) yayımladığı dokunaklı tahlile başvuralım. Bu noktada bazı şeylerin değişmiş olmasına ve hafızanın yıpranmasının başka yerlerde olduğu gibi Müslüman toplumlarda da etkisini göstermesine rağmen, buralarda köklü değişmeden daha çok kuvvet kaybı meydana gelmektedir. Bütün İslam ülkelerinde, Fas'tan Endonezya'ya kadar, ilk önce, kurucu, mevcut ve etkili kelâmı dinlemeden kimse bugün bile İslam'dan söz edemez. Kuran şüphesiz uzun zamandır milyonlarca mümin için oluşturduğu bilincin bir nevi nesnelleştirilmesi olarak tanımlanamaz. Fakat Müslümanlara daima bir başvuru odağı sunar. Kendisine başvuran herkese bol bol öğüt verir ve bireysel ve kolektif bilinçaltında rehber rolünü korur.

Konuyu açalım. Kur'an, çok eşit olmayan uzunluklarda, 114 surede ifadesini bulan, altı binin üzerinde ayetten oluşan yoğun bir bütünlüktür. Birisi 286 ayet kapsarken, diğeri sadece 3 ayet içerir. Böyle bir düzensizlik hangi ilkenin gereğidir? Tefsir, bu konuda, on dört yüzyıl boyunca kekelemektedir.

Düzensizlik izleniminin, biçimin ihtişamı önünde kaybolduğu doğrudur. $\mathrm{Bu}$ lisan dalgası (6.616 kelime olarak kümelenen 323.000'den fazla harf), eski şiirinkilerden daha etkili ve daha çekici, kafiyeli bir ritim ile titreşir. Sesin etkisi, on dört yüz y1l boyunca Arap retoriğinin/belagatinin hayranlık uyandıran anlamsal bir duyarlılık ve katmanlı çağrışımlarının bütünüyle anlamı

arasında Kitabü'ş-Şifa (Şifa Kitabı), mantık üzerine, fizik ve metafizik ve Kitabü'n-Necat (Kurtuluş Kitabı) adlı eserleri vardır. Onun "Oryantal Felsefesi" veya aydınlanmacı felsefesi, "ben”"i Tanrı'nın sezgisine, "Faal Ak1l"a davet eder.

18 İbn Rüşd (1126-1198): Ebu'l-Velid Muhammed ibn Rüşd, Latinler tarafindan Averroes olarak adlandırılmıştır. Aristoteles hakkındaki yorumlarıyla Batı'da ekol kuran bir hukukçu ve filozof olmuştur. Faslü'l-Makâl [Kesin Anlaşma] adlı eserinde, hakikate ulaşmanın tamamen aklî bir yolunu diğer yollardan ayırır ki bu yol, o devirde ciddi bir cesaret işiydi.

19 Büyük bir filozof, bilim ve düşünce adamı olan İbn Rüşd, Endülüs’te önce İşbiliye kadılığı, ardından Kurtuba başkadılığı görevlerinde bulunmuş, daha sonra da Merakeş’te saray tabipliği yapmıştır (BY). 
artırmaktadır. Bu, bazen çeviriye bile "yansır". En iyisi, "Nahl”/ "Arılar" Suresini (XVI) ikiye bölen olağanüstü pastorali/çobanlamayı dinleyelim:

65. (...) Evet, Allah, Gökten bir su indirdi de onunla Yeryüzüne ölümünden sonra hayat verdi.

- Bunda dinleyecekler için bir işaret vardır!

66. Her halde sizin için sağmal hayvanlarda da bir ders vardır. Bu hayvanların karınlarında kan ve keymus ${ }^{20}$ arasında bir nesneye dönüştürülen şeyden onlara içiriyoruz: saf bir süt, içenlerin boğazından kayar gider.

67. Hurma ve üzüm ağaçlarının meyvelerinden de hem müskir ${ }^{21}$ hem de güzel bir rızık çıkarırsınız.

- Bunda aklını kullanacaklar için bir işaret vardır!

68. Ve senin Rabb'in arıya vahyetti ${ }^{22}$ : Dağlardan, ağaçlardan ve kayalardan başlayarak göz göz evler edin.

69. Sonra bütün meyvelerden ye. Kendi hâlinde, Rabbinin yollarına koyul. İçlerinden muhtelif renklerde bir içki meydana gelir ki, onda insanlar için şifa vardır.

- Bunda tefekkür edecekler için bir işaret vardır!

\section{"Utanmıyorsan Dilediğini Yap"}

Ayraç I. "Görüyor musun?”, diye sözümü kesti şeyh, "uluslar geçer, ve sistemler de. İslam kalır. Sırf kibarlık olsun diye, geçici büyüklüklerinizden bahsetmeyeceğim. Sadece bizim taraftan bakınız: Salahaddin'den, Mehmet Aliden, Nasır'dan ne kaldı?"

Namaz saatinde ateşli kalabalıklar, Kahire'de Seyyidinâ'l-Hüseyin Camii'nin sundurmalarına doğru akın ediyordu, sonra ahenkli bir yürüyüşle geri dönüyorlardı. Gıdaların çekiciliği, oğlak eti uzmanı kebapçıların tabelalarında besinlerin görüntüleri sergileniyordu. Tabelalarda «size kısmet ettiğimiz hoş rızıklardan yiyiniz» (Kur'an II/57) ayeti ile reklam yapılıyordu. Her şey çevreye vicdan sükûnetiyle yansıyordu. Coşkun kalabalığın içinde, yarı örtülü

\footnotetext{
20 Keymus: Yiyecek ve içeceklerin midede kısmen hazmedilip erimesinden hâsıl olan bir sıvıdır ve kana karışır (BY).

21 Sarhoş eden, sarhoşluk verici şey, içki anlamına gelmektedir (BY).

22 Arıyı bal yapacak bir yapıda yarattı ve onu bu konuda eğitti (BY).
} 
güzel bir kadın, sağına soluna gizli bir cazibe salarken, Din ve ziyafet, erkeklerin cinsel istekleriyle kuşatılıyordu. Bununla birlikte, bir seyyar satıcı koltuğunun altına istiflenmiş tefsir kitaplarını Fişavî kahvesinin müşterilerine pazarlyordu.

Şeyh, Kanun ve Doğa'nın bu kalenderâne uzlaşmasına göre hükmediyordu. Ona Faslı lider «Allâl el-Fâsi`ninn²3 (1906-1974) bir cümlesini hatırlattım. 'Allal, SSCB'ne yaptığı bir gezi dönüşünde bana, Trans-Kafkasya'da davet edildiği bir şölen çıkışını anlatıyordu. Rus arkadaşı masanın altına yuvarlanmış ve o ana kadar sessiz kalan Özbek müftü, o zaman kulak tırmalayıcı bir Arapça ile ona içini açmış, kinlerini ve umutlarını fısıldamıştı. Ve 'Allâl sözünü şöyle tamamlamıştı: "Komünizm düşecek, fakat İslam daima var olacaktır”.

O vakit kendisine sormaya cesaret edemedim: “Hangi İslam?” Ama aynı soru, Misırlı Şeyh ile beraber, bu El-Ezher caddesinde yürürken durmadan benim kafamı kurcalıyordu. Söz konusu caddenin kitapçı vitrinleri, bana göre haddinden fazla bir biçimde, din bilgini Seyyid Kutub’un ve bağnazlığı ve şiddetiyle tanınan vaiz Mütevellî eş-Şa'râvî nin ${ }^{24}$ eserleriyle doluydu.

Sohbet arkadaşım, bu tür gözlem ve yorumlardan kaçındığından, nezaketen konuyu değiştirdim. Modern çağların muazzam örümceği gibi Fatımi şehrini bir otoyol şebekesi ile kaplayan şehir planlamasının kötülüklerini kınamaya karar verdik.

\section{Kur'an Ne Diyor? İman Başlıca Erdemdir ve Tıpkı Akıl Gibi, İnsana Yaratılışta Verilmiştir}

Kur'an ne diyor? Şimdiye dek İslam'ın aslî erdemi olarak kalan iman, insanı evrende (cosmique) sorumlu bir konuma yerleştirir. Erdem ona "asıl ubudiyet” biçiminde doğuştan ( $f$ itra) gelmiştir. Şüphesiz Vaby”in hem sosyal ve hem de metafizik ekseni budur. Bu eksen, geliş yönünde, görünür faziletleri için, ilk ahlakî değerlerden yoksun halkların felaketlerine çağrı yapan bir nedenbi-

23 'Allâl al-Fâsî (1906-1974): Faslı bir politikacı olan Allâl al-Fâsî, İstiklâl partisini kurdu ve Fas'ın bağımsızlığı için önemli bir rol oynadı. Bu olaydan sonra, ilk önce muhalefete girmeden önce Krallığın eleştirel bir destekçisi oldu. Şair, denemeci olarak o, Müslüman Batı'nın kültürel özgünlüğünü göz önünde bulundurarak İslami reformculuk çizgisi içinde yer alıyordu.

24 Muhammed Mütevellî eş-Şa ‘râvî (1911-1998). Mısırlı âlim. İslam’ın siyasî ideolojilerle ilişkisi olmadığını düşündüğünden bütün gruplara ve cemaatlere mesafeli davranmıştır. İslam’ın siyaset üstü bir din olduğunu savunmuştur. Kadınların mecbur kalmadıkça çalışma hayatına katılmasını reddeder. $\mathrm{Bu}$ ve benzeri görüşlerinden dolayı eleştirilmiştir. Doğrudan kitap telif etmemiştir. Konuşmaları başkaları tarafından kitaplaştırılmıştır. Bu tür altmış civarında kitabı vardır (Hilal Görgün, "Şa'râvî", DİA, 38, s. 350-351) (BY). 
lime (etiyolojiye ${ }^{25}$ ve gidiş yönünde, tezat oluşturan bir eskatologyaya/ahretbilime $e^{26}$ uygun düşmektedir: Bu eskatologyaya göre, bir yanda, kınananların cezalandırılması, diğer yanda seçilmişlerin sansüel/duygusal mutluluğu söz konusudur; bunlar, ancak zaten sırf alegorik/mecazî olabilir.

Bu yapısal çizgiler, içinde zamansallığın oynadığı konjonktürel çizgilerle yeniden kesişir: çağın olaylarına atıflar: mesaj iletişiminin teselsülü, tamamen beşerî vasıta olan habercinin bizzat kendisinin denemeleri üzerine ihtiyatlı ve aralıklı işaretlemeler. Bu koordinatlar Kur'an' 1 n her yerinde bir işleve sahiptir. Bu koordinatların bir şekilde düzene konulmadığı hiçbir parça bulunmadığ1 hususunda bahse girebiliriz... Dahası, bu sadece totolojik bir gözlemdir; Vahiy, son derece düzensiz iki kategori arasındaki -ilahi veya mutlak olanlar ile zamansal veya göreliler arasındaki- bir bağlantıyı ima eder. Skolastiklerimiz bu konuda deyimlerin iletişiminden bahsediyordu...

İslam, ayinler ve yasaklar konusunda önemli tasarrufu sayesinde Musevilikten ayrılıyordu. Hıristiyanlıktan farkını ise, doğuştan günahı reddetmesiyle, tabiattan yana tercihiyle, cinsellik konusunda komplekssiz tavırlarıyla ortaya koyuyordu. “...Tanrı'nın sizler için yazdığını arzulayın...” (Kur'an II/187). Kur'an'da iki yüz elliden daha fazla kural yoktur, diyor bazıları, diğerleri ise beş yüz diyorlar! Yetkin hadis yorumcusu Nevevîye dönelim. "Utanmıyorsan dilediğini yap”. Böyle bir ikileme cüret edilebildiği kadarına izin verilen bir buyruktur bu. Yasal bir yasak kapsamina girmeyen her eyleme müsaade vardır. Böylece, özgür iradeye ve öznelliğe bağlanmış olan ahlâk, bir emrin uygulanması kadar hayatın estetik alanıyla da ilgiliydi.

\section{Ayinlerde Tasarruf, Doğuştan Günahın Reddi, Aşkınlık İle İç İçe Doğalcılık}

Şurası bir gerçektir ki, uzun süreden beri, teoride savunulabilir olmamas1na rağmen, eski içtihatların takipçiliği, büyük yorumcular arasındaki dalgalanmaların özgürlüğü iyi kullanabileceği bir uzlaşmaya yol açacaktır. "Konformizme" 27 ya da "selef kültüne" (taklîd) karşı bütün savunmalara rağmen, 10. yüzyılın ortalarından bu yana hukuk bilginlerinin "öğretisel girişime" (ictihâd) hakkıyla başvurmaları aslında nadirdir; "yenilemeye" (tecdîd) ise daha da azdır; zaten "tecdid", genellikle "reform" (ılah)dan daha çok “dinsizlik” (bid'a) olarak nitelendirilmiştir.

\footnotetext{
$25 \quad$ Etiyoloji / Nedenbilim: Hastalıkların sebeplerinin incelenmesidir. Etiyoloji aynı zamanda bir ayinin ya da bir âdetin nesnel sebeplerinin araştırılması anlamına gelmektedir.

26 Eskatologya, dünyanın ve insanın sonuna ait teoriler ve hikâyelerle ilgili olduğu kadar diriliş ve mahşer ile de alakalı bilgi alanını ifade etmektedir.

27 Konformizm/Uymacılık, yerleşmiş gelenek, âdet, inanç ve düşüncelere itiraz etmeden, eleştirmeden uymaları anlamına gelmektedir (BY).
} 
Ayraç II. Psikanaliz uzmanı başını salladı: “Özetle," dedi, "İslam bir inverbation/kelamın-kitaplaşmast ${ }^{28}$ üzerine kuruludur; Hıristiyanların dedikleri gibi, bir enkarnasyon/tecessüm üzerine değil.

- Ama hayır! Diye protesto etti Şeyh. Kur'an'ın dili Tanrı'dan sadır olmuştur; bu dil başka hiçbir sebebe bağlı değildir.

- "Bizzat sizin söylemlerinize göre, Peygamber'in kabilesi Kureyş'in dili söz konusu olmasına rağmen, siz yine de bu kelamı doğaüstü bir güç ile donatiyorsunuz."

Kendi kendime ben, uzmanın derin bilgisine hayranlık duyuyordum. O Fas'ta doğmuştu, Arapça'yı çok güzel konuşuyordu. Sırası gelmişken, bu durumda aslında yine de bir beşerin konuşmasının söz konusu olduğunun belirlenmesi gerektiğini düşündüm; ancak söz konusu lisan, seçkin rolü sayesinde ve kendi sistemi içinde yeniden yapılandırılarak yüceltilmiştir. Tamamen dünyevî, üstelik dindışı değerlerle yüklü olan Arapça, başka bir dil, Kur'an' in dili, Vaby' in aracı olmuştur. Saussure ${ }^{29}$ tarafindan yapılan ayırıma göre, kasıtlı olarak bu iki kelimeye karşı çıktım. Psikanaliz uzmanı sözümü kesti:

"Ve aynı anda, İslam, diğer sistemlerde daha başlangıçta işaretlerin ham maddesini, onu ifade etmeye özgü lisandan ayıran açıklığ 1 bertaraf etmektedir. Böylece o, (Musa ve Mesih’in ardından) üçüncü olarak gelmiş olduğundan dolayı, köken bakımından günümüze yakın olmakla övünür. Ana gibi koruyan dil, onu babayı öldürmekten ${ }^{30}$ kurtarır. Yani, her anlamın başlangıç kırılmasıdır bu.»[Üç Tektanrıcılık içinde Daniel Sibony].

28 Kelamın-kitaplaşması (Inverbation): Kur'an Müslümanlar tarafından en mükemmel kutsal kitap olarak kabul edilir. Bu, Tanrı'nın kitap haline gelmiş kelamıdır/sözüdür (inverbasyon). Müslüman ilâhiyat ilk önce çok önemli bir konuyu tartıştı: Kur' 'an yaratılmış mıdır (mahlûk) ya da ezeli midir? Bilim adamlarının çoğu, Tanrı'nın sözü her zaman var olduğundan, Tanrı'nın sözü olan bir kitabın yaratılmış olamayacağını düşünmektedir. Öyleyse, Kur'an-ı Kerim, ezelî/yaratılmaksızın var olan ve ebedî/sonsuz olmalıdır: klasik öğretinin konumu böyledir.

29 Ferdinand de Saussure (1857-1913): İsviçreli dilbilimci, düşünceyi alt üst eden yeni bir yöntembiliminin yazarı. Dil, soyut sistem, toplumsal olgu, somut, hareketli ve bireysel bir gerçeklik olan sözden ayrılır. Anlam, yapılandırılmış bir farklılıklar sistemine dayanır, ve anlatan ile anlatılan arasındaki ayrım, simgenin genel teorisini ortaya çıkarır ki buna semiyotik/göstergebilim denecektir. Ferdinand de Saussure'ün ölümünden sonra yayımlanan Cours de linguistique générale adlı eseri, çağdaşları üzerinde büyük bir etki uyandırdı (Benveniste, Levi-Strauss, Merleau-Ponty, Lacan). Bu etki, dilbiliminin ve sosyal bilimlerin birçok dalının bugünkü gelişmesini haber veriyordu.

30 "Babayı öldürmek" / "baba katli", bütün toplumlarda söz konusu olan mitolojik bir kavramdır. Babanın temsil ettiği otoritenin yok edilişi, oğulun babanın gücünü elde etmesi anlamına gelmektedir. Bu sembolik olayın muhtelif bilim dallarınca tahlili yapılmıştır. Freud, konuyu "ödip kompleksi”" çerçevesinde psikanalitik açıdan ele alır (BY). 


\section{Küresellik (Globalité) Bilinçliliğinin/Sezgisinin (İmmédiateté) “Özgür Hareket"inin Dini}

Tartışma hedefinden uzaklaşıyordu. "İslami başörtüsü" kavgası, konuştuğumuz anda bile, Fransa'yı işgal ediyordu. Ülkemizin laikliği, çoklarının gözünde, tehlikeye giriyordu, dinî ve kültürel bir çoğulculuğa göre, laiklik onun hoşgörüsünün ilan edilmiş kaçınılmaz şartı idi. Tartışmayı genişletelim. Kadının statüsünün ve dış simgelerinin, bir toplum için tekâmülünün önemli bir ölçütünü oluşturduğu söylenemez mi? Ve işte tam bu konuda, İslam'ın dünyanın genel gelişmesine intibakı, ekseriyetin gözünde, başarısız kalmaktadır.

III. TUTARSIZLIKLAR. İslam, gerçekten dünya kamuoyunda, ne kınanan olmaktan çok korkulan Japonya ile, ne gözetilmesi gereken olağanüstü bir müşteri Çin ile, ne de metafizik eğiliminin tehlikesiz hale getirdiği bir dev olan Hindistan ile paylaşmadığı bir itibar kaybı yaşamaktadır. Bizzat Müslüman, ancak en kötüsüyle anlaşabileceği bir modernite/çağdaşlık tarafından çok daha tehlikeli kılınmış ebedi Sarazen ${ }^{31}$ durumundadır. Saddam'ın Irak'ında olduğu gibi, atom bombasıyla donatılma kabiliyeti ve geri-kalmışlik bir arada bulunmuyor mu? Dürüst olalım. İslam, özel stratejilerden daha çok, böyle bir istisna sayesinde, kabullendiği ve orada -"geriye kalanı üstelik kendisine tabi kılan"- bir sığınak aradığı izlenimi uyandırmaktadır. Giderek daha din-dışı hale gelen bir dünyada, Tanrı'yı yüceltmek, hatta beş vakit namaz kılmak; herkes dünyevilik/ sekülerlik için mücadele ederken siyaseti dine bağlamak; son olarak durumların ve düşüncelerin genel ivmesi içindeki şu-anın kalbinde ilk mesajın hafızasını anıtlaştırmak, bu türlü tutumlar, tehditlere karşı olduğu kadar iyi davranışlara karşı da direnmektedir. Bu direnişte Hıristiyanların oynadığı büyük role, Suriye, Sudan ya da Libya'dan çıkan terörizmin tehditlerine, Cezayir'de entelektüellerin öldürülmesine, vs. rağmen, uluslararası kamuoyu, Filistinlilerin yenilmezliğini işte bu büyük direniş̧̧iye atfedecektir.

\section{Ne Yazık Ki, Batılılar İçin Müslüman, Genellikle Lanetlenmiş, Saldırgan ve Ebedî Bir Sarazen Olarak Kalmaktadır}

Başlıca üç ana suçlama üzerinde sükûnetle durmayı deneyelim: bazen terörizme kadar varan bir saldırganlık; din görevlisini siyasette harekete geçirme eğilimi; insan haklarına bağl1likta belli bir isteksizlik... Bu konuda bugün kadın hakları en güvenilir kıstastır.

31 Sarrasin (Sarazen) kelimesinin, Arapça şarkıyyûn kelimesinden galat olduğu sanılmaktadır. Ortaçağda Endülüs ve Kuzey Afrika Araplarına verilen bir addır. Araplara mensup anlamına da gelir. 
Saldırgan mı? Batı'da demokrasi ağır ağır ve güçlükle epey yol almıştır. Ve buradan hareketle de bir ölçüde her yerde... Eğer bu, gerçek ya da varsayılabilir iyi bir tekâmül ise, bu tekâmülün, maruz kalınan saldırının devamının, adaletsizlik duygusunun Müslümanların ekseriyetinin davranışı üzerinde yarattıkları ters tepen etkileri hala bertaraf edemediğini de kabul edelim; bunun sorumluluğunu, birbiriyle uyumlu bir dinamik üstlenmediği içindir ki, durumun böyle olduğunu da bilelim. Lakin ileriye yürüyüş, duraksamakta ve yalpalamaktadır. Bazı hareketler veya partiler ret bayrağını sallamakta, sorunları çözmenin ve -savunmanın başarısız olduğu yerde- başarmanın tek yolu olarak şiddete başvurmaktadırlar. Gizli eylemin cazibesini veya zorunluluğunu, rakibin orantısız araçlarını sadece beli bir mücadele tipinin dengeleyebildiği gerçekliğini de ekleyelim; işte o zaman, helikopterlere ve zırhlı araçlara sahip olmayanlar için çok çekici bir silah olan terörizmin baş gösterdiği görülecektir.

$\mathrm{Bu}$ etkileyici hazin olaylara atıfta bulunmak, onların kolektif olduğu kadar ferdî ajanlarını ve bir metafizikten daha çok, övündükleri motivasyonları/isteklendirmeleri sorgulamaktır. Onlar yine de eylemlerinin dayanağı olarak İslam'a başvuruyorlar. Şurası teslim edilecektir ki, Kur'an, bu tür yıkımlara, Haçlı Seferleri döneminde İncil'in Frank Baronlarının katliamlarına katkısından daha fazla bir katkıda bulunmamaktadır. Didaktizmle yanlış yapma riski pahasına, işaret edelim ki, c.h.d. ${ }^{32}$ kelimesinin kökeni sadece «çaba», «ağrı» anlamına gelmektedir. En övülen ve en büyük cihad ${ }^{33}$, ilahiyatçılara göre, iman sahibinin kendisiyle ilgilidir, kendi öz tutkularına karşı yapılan cihaddır. Küçük cihada ${ }^{34}$ gelince, Kur'an'a göre, o, her şeyden önce savunmac1 bir içeriğe sahiptir. İmanın uygulanabilmesi durumunda küçük cihad, tüm meşruluğunu kaybeder. Günümüz Avrupa’sında durum açıkça budur.

32 Özgün metinde, j.h.d. biçiminde kaydedilmiştir (BY).

33 Özgün metinde, jihad biçiminde yazılmıştır (BY). Cihad: Etimoloji / Kökenbilim açısından, cihad belirli bir amaca yönelik çaba, örneğin kendini olgunlaştırma amacıyla nefis üzerinde gösterilen gayret anlamına gelir. C.h.d kelimesinin kökü sadece "çaba", "acı, zorluk" manasını hedef alır. Genel klasik doktrine göre ve tarihî gelenek içinde, cihad, İslam'ın ve muhtemelen onun anlatımının savunulması gayesiyle silahlı eylemden oluşmaktadır. Prensip olarak cihad, İslam'da anlaşılabilir tek savaș biçimidir. Aynı zamanda, enikonu düşünüldüğünde, doktrin veya hukuk bilimi ile ilgili konularda ictihadın, "girişim"in kanonik ifadesi de bu kök ile bağlantılıdır. Bir özdeyişe göre, Hicret'in dördüncü yüzyılından bu yana, yani tahminen Miladi onuncu yüzyıldan beri, yerini tradisyonalizme/gelenekselliğe ve konformizme/uymacılı̆̆a (taqlid) terk eden "ictihad kapısı kapanmıştır".

34 Özgün metinde, jihad biçiminde yazılmıştır (BY). 


\section{Gerçekten Saldırgan Mi? O Kendini Olabildiğince ve Tehlikeli Bir Biçimde Savunuyor}

Siyasette din. Mart 1924'te, Türkler halifeliği kaldırdıklarında, dünyadaki Müslüman topluluk (umma) kurumsal bir kadroyu kaybetti; bu kadro, uzun süredir ve pek çok ülkede sadece itibarî/saymaca bir varlık gösterdiğinden, hâlâ kısmen sembolik bir değere sahipti. İslam Devleti'nin artık ne dayanağı, ne meşruiyeti ne de yasallığı vardı. Sartre o sırada, onun kolektif ÖzGüvenini (Sur-Moi) kaybetmiş olduğunu söylüyordu.

Sömürge döneminin analizcileri olayı gerçek önemine layık bir biçimde değerlendirmediler. Bununla birlikte, Hindistan'da Hilafet ${ }^{35}$ Hareketi'nin Hint köktenci iddialarını ve bize daha yakın olan Mısır'da Reşid Rıza'nın ${ }^{36}$ kanunî 1slahatç1lığını eylem ya da tepkiyle tetikleyen hilafet olmuştur. Bize göre, Gandi Hindistan'daki Hilafet hareketiyle paradoksal ilişkiler geliştirdi. Reşid Rıza'nın ıslahatçılığı ise, Tunus ve Cezayir'de aynı ilhamdan kaynaklanan hareketlerin tohumların atıyordu.

$\mathrm{Bu}$ ekol için, insanoğlunun muhtelif kategorileri arasında ilk ve temel bölünmezlik, bir taban verisi oluşturur. Dîn ve dünyâa ${ }^{37}$, "alçak-dünya ve ÖtekiDünya": iki terimi birleştiren rabıtanın ayn zamanda onları ayırdığına dikkat etmeksizin, sivil kurumu tanrısala (théologal) eklemleyen bir ana formül. Aslında elbette bölünmezlik, hatta yakınsaklık söz konusudur, bunu daha önce zaten söyledik, ancak karışıklık yoktur. Bununla birlikte, bizler tarafindan "İslamcılık", ya da "köktencilik"/"fundamentalizm" veya "entegrizm" diye nitelendirilen hareket, bu geniş yorumdan kaynaklanmaktadır. Bu yorumdan hareketle, İslamcı Cemâtü’l-İslamı̂ partisinin kurucusu Pakistanlı düşünür Mevdûdî (1903-1980), maneviyattan daha çok siyaset üzerine odaklanmış bir ideoloji sistemleştirdi. Onun tezleri, dava uğruna şehit düşmüş olan sezgisel yorumcu ve aktivist Seyyid Kutup'un eserlerinde etkin bir yardımcı bu-

35 Halifelik: Fransızca Califat, halife deyiminden türetilmiş bir terimdir. Müslüman hükümdar ve Muhammed'in ardılı demektir. Bunun uzantısı olarak hilafet, hükümdarlığı ya da hanedanı süresince, halifeye bağlı topraklardır. Hilafet kurumu, Peygamberin ölümünün hemen ertesinde, toplumun yeni başkanı Ebu Bekir, Peygamber'in idari ve siyasi görevini üstlendiği yani onun ardılı olduğu zaman doğmuştur. Mart 1924'te Türkler hilafeti kaldırdılar ve umma kurumsal kadrosunu kaybetti. Hilafetin çöküşü Mısır'da, Şeyh Ali Abdu'r-Razik'ın İslam ve iktidarın kaynakları hakkındaki cüretli tezinin (1926) yazılmasına vesile oldu; bu tez, anayasal hukuku laikleştirmeye yönelik bir girişimdir ki, büyük bir skandala yol açmış ve maalesef arkası gelmemiştir.

36 Reşid Rıza (öl. 1935): Suriye-Lübnan kökenli olan Reşid Rıza, İslami doktrinin aslî saflığına geri dönüşünü savundu. O, reformculardan biriydi. Reformcuların gözünde İslam, hoşgörülü ve aklîdir, ilerlemeye düşman değildir, Batıyı ileri geçemediği zaman onların teknik inovasyonlarını kabul eder. Reşid Rıza'nın “el-Menâr” dergisi, İki-Harp-Arası'nda büyük bir entelektüel rol oynadı.

Özgün metinde, böyle yazılmıştır (BY). 
luyor. Yoldaki İ̧aretler adlı kitabı, öğreti ile ilgili muhalefetin şiddete geçişini örgütleyecektir. Bugün, onun Misırlı müritlerinden birisi olan Abdüsselam Farac, bu şiddeti laiklik taraftarlarını idam ettirme sözü verecek kadar ileri götürmek zorunda kalmaktadır.

\section{İslam, Siyasî Sapmalara Elverişli Bir Kimlik Sembolü Olmaktadır}

Bu arada İran bir devrim girişimi başlatmıştı. Şah'ın Batı'nın bir kalesi ve daha doğrusu Amerika'nın savunma üssü haline getirmiş olduğu bir ülkeden sürülmüş olan bilimci Ayetullah Humeyni ${ }^{38}$, şî̀ Mollaların [din adamlarının] çok dilli propagandasına dayanarak (1979) iktidara geliyordu; bu bir nevi iktidar tarafindan kontrol edilemeyen brovniyen ${ }^{39}$ bir hareketti. İslam Cumhuriyeti, üzücü bir saldırıyla işe başladı: uluslararası kurallara hiç aldırış etmeksizin, bir yabancı elçiliğin abluka altına alınmasıydı bu...

Din, 19. yüzyılda, Medine devleti örneğinde geçici bir İslam devletinin kurucusu Sudanlı Mehdi döneminde, ya da mesela, Tolstoy'un Hacı Muad'ında (1903-1904) anlattığı asi şef Kafkasyalı Şamil'in döneminde yapmış olduğu gibi artık zulme karşı desteğini önce İran'da, sonra Sudan'da ve diğer yerlerde, sadece acemice bir direniş olarak sunmuyor. Bu destek, artık sûfilerin ${ }^{40}$ eskiden yapmış oldukları ve hala yapageldikleri mistik kaçış davranışları gibi de değildir. Hatta Mısır'da Hasan el-Benna'nın ve ardıllarının Müslüman Kardeşler benzeri sıra dışı bir partinin direnişine de benzememektedir. Fakat artık Batılı siyasetleri gerileten dinden, hem yıkıcı ve kuramcı, hem kaynayan ve örgütlü bir biçimde yararlanılmaktadır ki, burada yeni bazı şeyler söz konusudur.

Doğrusunu söylemek gerekirse, her zaman geleneklerle beslenen müminlerin vazgeçilmez tabanına dayanılmaktadır; bunlar öyle bir kitledir ki, geçen yüzyılın evrimi, onların davranışlarını çok az etkilemiştir. Kuşkusuz bu kitle,

38 Ayetullah Ruhullah Humeyni (1902-1989): İranlı bir ilahiyatçı olan Humeyni, tahsilini Kum‘da yaptı; 1960'tan itibaren orada Şii “din adamları” nın yüce rütbesi olan Ayetullah unvanını aldı. Muhalif davranışlarından dolayı hapsedildi, sonra Necef'e (Irak) sürüldü ve ardından Fransa'ya iltica etti. Şah'ın ayrılmasından sonra İran'a döndü. Eserleri arasında Velâyet-i Fakih [bilim adamı için Naiplik] en önemlilerindendir. Bu eserde, hükümetin yönetiminde ulemanın (İslam doktorlarının) üstünlüğünü iddia etmektedir.

39 Brovniyen hareket: Sıvılar içinde bulunan mikroskobik varlıkların hareketi, devinmesi (BY).

40 Sufiler: İslam'ın tasavvuf erbabı. Arapça kökenli bir kelime olan 'soufisme'/sufizm terimi (sufiden türetilmiş terim, sof, "yün” ile bağlantılı olduğu söylenen bir kelimedir; münzevilerin giydikleri kaba giysiye atıf yapılmaktadır), tam olarak Müslüman mistiki belirlemek için kullanılmaktadır. Uygulamalarında ve doktrinlerinde genellikle farklılaşan çok sayıda akımı kapsar. Sufizm, Sünni ortodoksluk tarafından reddedilmesi sebebiyle genellikle tepkiler uyandırmış olsa da, tamamıla dinî bir hareket olarak, İslam'da kabul edilmektedir. 
Harp-Sonrası nesilde, Nasır dalgasıyla hareketlenmiş ve bir takım sosyal propagandaların tesiri altında kalmıştır. Rejimlerin çöküşü, kaybolmuş hayaller, Filistin meselesinin uyandırdığ maya sevk etmiştir.

Çare İslam'dı. İslam, bu defa, binlerce yılllk hareketlerin ve sûfî tarikatların vaktiyle anlamış olduğu biçimiyle modernliğin muarızı olarak değil, demokrasinin alternatifi olarak, gelişmenin özel yolu olarak değerlendirilmektedir... Kadın hakkı. Türkiye'den söz etmesek bile, Pakistan ve Bangladeş gibi iki büyük Müslüman ülkenin başında kadınlar vardır. Bununla birlikte, İslam'da geçmişe oranla kadının durumunun genel olarak iyileştiği söylenemez...

Ayraç III. Bizi dinleyen eski Desturî ${ }^{41}$ militanı irkildi. Bize, Tunus'un kurtuluşundan bu yana, Burgiba'nın kadını hürriyetine kavuşturmuş olduğunu hatırlattı. Örneğin, Mısırlı gibi, diğer yasa koyucuların, pek arzu edilmeyen bir kadere sağlamış oldukları bir takım iyileştirmeleri ufak tefek şeyler diye küçümseyerek, o, ilk hamlede, asıl soruna hücum etmişti: çok eşlilik ve tek taraflı boşanma. Bu olay, 50’li yılların sonunda, bağımsızlık şenliği sırasında cereyan etmişti.

"Şüphesiz", diye mırıldandı Tunuslu, "Şimdi daha da ileri gitmek gerekecektir, çünkü hala kadınlarımızı ezen ayrımcılıkların, ülkemizin büyük evrimini felce uğrattığı son derece doğrudur. Kur'an̂े temeli sağlam olmayan peçeyi saymıyorum, eve kapatılmayı da. Ne biri ne de diğeri, Bedevilerde asla kullanılmamıştır ve yüzyılın başından bu yana her yerde gerilemekte iken, bugün aksine, köktendinciliğin yardımıyla, saldırganca dönüşleri söz konusudur”.

- Yani, gerçek ayrımcılık başka bir yerde mi?

- Hayır, çünkü mirasta kadın için yarım pay ayrılması ve tanıklıklarda kadınların yarısının hesaba katılması şartını hükme bağlayan Kitap, aynı sûrede bu indirgemenin (terimin hukuki anlamiyla) 'sebeb'ine temas etmekte ve bu eşitsizlikleri aynı yolla gidermeyi telkin etmektedir.

-Yani?

- "Erkekler, Tanrı'nın kadınlara göre onlara sağladığı elverişlilikten ve kendi öz mülklerinden harcadıklarından dolayı onları üstlenirler ${ }^{42 ”}$ (Kuran

\footnotetext{
41 Tunus’taki Sosyalist Desturî Partisi (el-Hizbü'l-İştirakî ed-Desturî) militanlarına atıf yapılmaktadır. Bu parti, Habib Burgiba tarafından kurulmuş ve 1964'ten 1988'e kadar iktidarda kalmıştır (BY).

42 Zımnen, "kadınların korunmasını ve ihtiyaçlarını üstlenirler”, J. Berque, Le Coran, s. 101, not: 34.
} 
IV, 34). Modernitenin kadınları gitgide donatmış olduğu sosyo-ekonomik özerklik sayesinde, kadınların artık, kendileri üzerindeki söz konusu "avantajı kaybeden erkekler tarafindan "üstlenilmemiş" olduklarını derinliğine düşünecek kadar cesur bir Müctehid ['kuramsal konularda' öncü olmaya muktedir bir uzman'] hayal edelim.

Şeyh itiraz etti. Bana gelince, ben, taraf tutmaya cesaret edemedim. Tunuslu sustu. Ve biz, hep beraber, Kahire'nin eski ve göz alıcı mahallesi Cemaliye'yi, Necip Mahfuz'un birçok romanının ve öyküsünün geçtiği köhne meydanı birlikte ziyaret etmenin daha uygun olacağını düşündük.

Kur'an ne diyor? "Nisa / Kadınlar" adlı dördüncü Sûre, ilk ayetten başlayarak, kadın varlığını erkeğe eşit yaratılış onuru içine yerleştirir. Lakin bu akran, "mutlak öz, kırılmış varoluş», hemen yetim hâline düşer (Kur'an, IV / 2,3).

Tek eşlilik mutlak bir tercih olmasına rağmen, çok eşliliğe müsamaha edilmiştir. Ancak o çağın sınırları kapsamında verilmiş olan bu imtiyaz, bununla birlikte, henüz arkaik olan bir toplum tarafindan, bir hak olarak yorumlanmıştır. Tefsir, daha da ileri gitti. Bizzat Kur'an'ın telkinlerini göz ardı ederek, onun hatalı eşin affedilmesi için çağrılarını yok sayarak, zorlayıcı yönler üzerinde ısrar etti. İki ya da üç Hadis’e dayanarak, zanî kadının taşlanması için, el yazmalarının karşılaştırılarak derlenmesi sırasında unutulmuş sözde bir ayete bile başvurdu! Tanrı'nın hükmü artık sofiyane biçimde yönlendirilemez...

$\mathrm{Bu}$ tefsir sorunu her ne olursa olsun (zaten bu konuda Haricîler denen bir mezhep, Müminlerin ekseriyetine uymaktan kaçınmaktadır), kesin olan bir şey vardır: İslam dıştan gözlemcinin dikkatini erilliği ile çekmiştir ve hala da durum böyledir. Bunun, Vahiy'den ziyade taşıyıcı toplumların özgüllüğünden kaynaklandığı açıktır; işin bu yönü, bu bölümde zikredilen diğer hususlarla birlikte, Müslümanlar için uyum sağlamakta güçlük çıkartmaktadır. Modern dünyada gerçekten kadınların statüsü, haklı olarak toplumların ilerlemesinin kıstaslarından biri haline gelmiştir. Vasiyetle ve tanıklıkla ilgili olarak zevcenin haklarının aşağılığı gibi hususlarda ayrımcı özellikler; boşanma konusunda kadın ve erkek cins arasındaki güçlerin dengesizliği; nihayet dipten gelen üç ya da dört nesil sonra, bazı çevrelerde tekrar bir kimlik şartı olarak tezahür eden başörtüsünün yeniden gündeme oturması, üzerinde derinliğine düşünülmesi gereken önemli sorunlardır.

IV. HATIRADAN GELECEK ÇIKAR MI? Bağdat'in gezmekte olduğumuz Mustansırîyesinin, görkemli manzarası sohbetimizin konusuydu. $\mathrm{Bu}$ ülkeyi ilk ziyaretim sırasında (1956), bu mahalleyi gerçek bir harabeler alanı 
olarak tanımıştım. Bugün artık pürüzsüz yüzeyler, muhteşem görünüşler, enfes oymalarla bezenmişti. Benim hayranlığım, eleştirinin yolunu açtı. "Bizim mimarlarımız", dedim arkadaşlarıma, "bir Yunan tapınağını restore ettiklerinde, özgün esere yaptıkları eklentileri algılanabilir farklilıklar ile işaretlemeye dikkat ederler: Meselâ, taşınmış sütunların kırılan bölümleri üzerindeki yivlerin bulunmaması buna örnektir. Hâlbuki 13. yüzyılın şu Medresesi [okul, talebe yurdu], aynı düzeyde çağımıza taşınmıştır”.

Iraklı mimar bana, "restore etmenin", onlar için, varoluşsal bir sürekliliği yeniden tesis etmek olduğunu ve bir inceleme nesnesini mezardan çıkarmak olmadığını açıkladı. Ve ben kendi kendime içimden Heidegger'in ${ }^{43}$ ünlü formülüyle İslam'ı hedef alabileceğini söylüyordum: "Hazır-bulunma, Ezel'in hükmüyle gelecektedir”.

Canlılık, zamansallık... İslam, Değişmezin onaylanmasını ister. Yüz binlerce insan eşzamanlı olarak ve eğer istenirse, paradoksal olarak/aykırı biçimde, devamlılığının ve zamansallığının tanıklığını yapar. Onun için sorun, ne kalmak, ne kendine inanmak, hatta ne de değişken ve göreli bir dünyaya katılmaktır, beriki ve öteki arasındaki bağlantıyı kurmaktır. Bu, çağların değişmesi ve ortamların çeşitliliği çapında bir sorunsal oluşturmaktır. Bunu yapar mı? Ya da bunun zaruretine inanıyor mu? En azından hiçbir şey kesin değildir. İşte, İslam ıslahatçılarının gayreti bu istikamete yönelmelidir.

Anladığım kadarıyla, yukarıda işaret edilen karakterin/varoluş tarzının özelliği hesaba katıldığında, her aggiornamento'nun ${ }^{44}$, kendisi için geçmişe dayanmak zorunda olduğunu düşünüyorum. Baas gibi laik bir partinin teorisyeni olan Michel Aflak'ın (1910-1989) bile programına yazdığı bu "asliyyetl özgünlük» (assala) mefhumu buradan gelmektedir. Asala ve Mu'âsara, “özgünlük içinde modernlik”, bu ifade, Nasır'ın Kahire'nin bininci yıldönümü kutlamaları için yaptığı konuşmasının (1969) en etkili formülü olmuştu. Faslı düşünür M. Abed al-Jabri ${ }^{45}$ de, yenilenme ve "miras" (turâth) arasında bu tür

43 Martin Heidegger (1889-1976): Alman filozofu, 1928-1934 yılları arasında Breisgau'da Freiburg Üniversitesi rektörü. Nazizm ile uzlaşmaları yüzünden çok tartışılan Heidegger, yenilikçi eserlerin yazarıdır. Bu eserlerde o, varlık, zamansallık ve lisan (langage) hakkında kendisini sorgulamaktadır (L'Etre et le Temps / Varlik ve Zaman 1927; Kant et le problème de la métaphysique / Kant ve Metafizik Problemi, 1929; Qu'est-ce que la métaphysique / Metafizik Nedir, 1929, vs.)

44 Yazar burada bu İtalyanca kelimeyi kullanmıştır. Aktüel dünyanın evrimine, terakkiye uyumsağlama, güncelleme anlamına gelmektedir (BY).

45 Muhammed Abed al-Jabri: Yenileme/yeniden doğuş ile "miras" arasındaki irtibatı sağlamaya çalışan Faslı çağdaş filozof. Abed al-Jabri, Rabat Üniversitesi'nde profesördür ve şu iki eserin yazarıdır: Nakd el-akl el-arabi [Arap Akl'nini Eleştirisi], 1992, ve Introduction à la critique de la raison arabe / Arap Aklinin Eleştirisine Giriş, 1994. 
bir bağlantıyı gerçekleştirmeyi amaçlamaktadır. Böylece İbn Rüşd çizgisi yakalanacaktır. Bu çok verimli bir felsefi konumdur. Lakin kitlenin çözümleri, sadece "ameli/uygulamalı akıl” yönünden sezinlenmektedir ki, o, İbn Rüşd'ün bile derecelendirmesinin ikinci aşamasına ittiği ve büyük bir yargıç olarak uyguladığı akıldır. Neden? Çünkü İslam, her zaman dayanakların yönlendirmesini elde etmeye çalı̧̧ı̧s ve fukahaya ["alimler"e ve özellikle "hukukçular"a verilmiş] bu görevde, halkların güvenini hiçbir zaman kaybetmemiştir. Bu bağlamda, Mısırlı bir düşünür olan Hasan Hanefínin ${ }^{46}$ araştırması bize yetkin ve sağduyulu gözüküyor. Bu araştırma, onun, alışık davranışlar seviyesinde filizlenen hukuk biliminin yenilikçi bir eleştirisi sayesinde, yavaş yavaş ilkelere kadar gidecek olan bir yenilenmeyi ortaya çıkarmaya çalıştığı dikkatli bir çalışmasıdır.

Kabul edilemez. Diğer çabalardan bahsedilebilir. Bu gayretler, şimdiye kadar, modern araçların (basın, televizyon) oybirliği ile eski dönemlere nazaran daha anlaşılmaz hale getirdiği bir muhafazakârllğg üstün gelemediler. İslam'ın ilk yüzyıllarında, firkaların ve mezheplerin savunucularını -ki bunların sayısı yetmişlerin üzerindedir- birbiriyle karşı karşıya getiren durumdan kesinlikle çok daha baskıcı bir hâl. O zamanların gelişmesi, tabi ki, hiçbir vakit özgür düşünce hakları arayışı içinde olmasa da, bir zihinler kaynaşmasına, bir hakikate bağll1ığa, bir fiilî çoğulculuğa, daha az tanık olmuyordu, bugün bunlar boş yere aranacaktır.

Buna mukabil, sansürlerin ve kovuşturmaların canlanması, muhakemenin yerine lanetlemenin geçmesi, fikrî tartışmaların yerini kayıtsız şartsız suikastın alması esefle gözlemlenmektedir. Farac Foda ${ }^{47}$ (Favd) böyle düştü, Nobel ödüllü Necib Mahfuz ${ }^{48}$ hançerin itirazına böyle uğradı, Cezayirli entelektüeller her gün böyle ölüyorlar. Ve, hapiste ölmüş olan, uluslararası kültürün İranlı düşünürü ve şairi İhsan Tabarî (1916-1989) ile birlikte denebilir ki, Mollaların İran’1 korkunç bir şekilde intihara götüren bu sersemliğin yolunu açmıştır.

46 Hasan Hanafi: Çağdaş Mısır düşünürü, el-Turās ve’t-Tecdîd [Miras ve Yenilenme.] adlı eserin yazar1.

47 Farac Foda: Mısırlı gazeteci, çok hür bir tonda makalelerin ve broşürlerin yazarı, 1993 yılında katledilmiştir.

48 Necib Mahfuz (1911- ): Oldukça önemli eserleri olan Mısırlı romancı, Kahire'nin eski semtlerinin gerçekçi resimleriyle çalışmalarına başladıktan sonra, giderek toplum hakkında daha yenilikçi, sorgulayıcı ve bazen de eleştirel bir bakış geliştirdi. Sofular/sahte dindarlar, Necib Mahfuz'u, üç tek tanrıcılığın birbirinin mirasçısı olduğunu, uygunsuz bir biçimde, Evlâd Hâratinâ, 1954 [mahallemizin oğlanları] adlı romanında, anlatmış olması iddiasıyla ayıplıyorlardı. Bu sebeple bıçaklanmıştır. Söz konusu kitap, Les fils de la Médina ismiyle Fransızcaya çevrilmiştir, 1991. Kahire dergisi, El-Qahira, bu davaya "Kalem ucu ve bıçak" (Kasım 1994) başlığıyla özel bir sayı ayırdı. Necîb Mahfuz, 1991 yılında Nobel Edebiyat Ödülü’nü aldı. 
Benzer bir durumu tanımlamak, İslami süreklilik açısından da değerlendirildiğinde, bunun kabul edilemez niteliğini ortaya çıkarmak anlamına gelmektedir. Kökenden beslenmeyi talep eden bir süreç için, kaynakların bilgisinden kaçınmak, inandırıcı olmaz. Bu bilginin modern yöntembilimlerden haberdar olması gerekir; onun böyle bir girişten nasıl yan çizebileceği ve entelijensiyaların özgür araştırmalarından nasıl korunacağı görülmemektedir.

Bir başka endişe verici özellik, bazı insanlarda, gerçekte, imanı savunmanın aldığ1 yabancı düşmanlığı görüntüsü... Hiçbir şey İslam’a yabancı değildir! Peygamberin Sahabesi arasında bir Afrikalı, bir İranlı ve bir Yunan kabul görüyordu; gel gelelim, Habeşlinin öyküsü çok daha geniş ufuklar açıyordu ${ }^{49}$. Bununla birlikte, siyasi eşitsizlik anlamındadır ki, fethin ilk yıllarından itibaren, Müslüman Devlet'in Kitap Ehli ile ilişkileri ortaya çıkmıştır ${ }^{50}$. Bu dengesizliklerden bazıları, eğer deyim yerindeyse tersine dönmüş bir vaziyette, hala uygulanmaktadır: Kuzey Afrikalıların, Türklerin, Müslüman Afrikalıların yüz binlercesi, artık geçici veya kalıcı olarak batı kentine yerleşmektedirler. Ne yapmalı?

Ayraç IV. Hindistan kökenli bu şeyh, Hindistan ve Pakistan'ın ayrılmasından bu yana Paris'te yaşıyor, hala bu bölünmenin sorumlusu olarak Gandi'yi görüyor. Onun ince silueti kütüphaneleri ve Fakülteleri sık sık dolaşır. Azîm, onun derin bilgisidir, züht rejimi. Günde bir avuç hurma ve bir şişe süt ile ya-

49 Peygamberin hayatının Habeşistan safhası: Hicret’ten (ilk Müslümanların Medine'ye kitlesel göç etmesi) birkaç yıl önce, zulüm öylesine arttı ki, Muhammed, bir grup taraftarını Habeşistan'da sığınma hakkı aramaya gönderdi. Bu ülkenin Hıristiyan hükümdarı onları çok iyi karşıladı. Gelenek, bu Arapların İsa ve Kutsal-Bakire'yi (Meryem) derin bir saygı ile andıklarını duyunca duygulanarak gözyaşlarını tutamadığını nakleder.

50 Diğer dinlere saygının tarihsel geleneği: İslamiyet'in (en azından Arap yayılmasının ilk günlerinde) kılıçla yayılmış olduğu fikri terkedilmiştir. Çünkü kaynakların eleştirel tetkiki, galip Arapların yenilenleri asla din değiştirme veya imha edilme alternatifi arasında bırakmamışlardır. Onlar Kitap Ehli'ni (Yahudileri ve Hiristiyanları) bir cizye ödemeye ve hükümdara biat etmeye zorunlu kılıyorlardı. Buna karşılık, kendilerini yönetme hakkını koruyorlardı. Bu zimmî statüsüdür:

"Ehl-i Kitap ile, en güzel bir üslup dışında tartışmayınız, haksızlığı ispat edilmiş olanlar elbette müstesna. Mesela deyiniz: 'Bizler, bize indirilene ve size indirilene inanıyoruz. Tanrımız sizinkiyle tek bir Tanrı'dır. Biz O’na teslim olduk' “Kur'an, XXIX, 46 (Çev. J. Berque).

Muzaffer Araplar, kısa süre içinde İran’ın Zerdüştîlerini Ehl-i Kitap ile eş tutmakta gecikmediler. Sadece Müslümanların başlangıçta nadiren uğraşmak zorunda kaldıkları putperest paganlar, daha sert muamelelere maruz kaldılar. Fatihlerin en önemli uğraşları, hiç bir yerde mağluplara doğrudan din değiștirtme değil, fakat kendi öz hegemonyalarının kurulması ve bunun tabii sonucu olan verginin organizasyonu gibi görünmektedir. Hikâye, Halife Ömer’in yalnızca birkaç arkadaşıyla Kudüs'e girmek istediğini anlatmaktadır. O, Patrik Sophronius'tan, dini geleneğe adanmış bütün yerlerde kendisine eşlik etmesini rica etti ve daha sonra bölgenin sakinlerine, güven içinde olduklarını, mülklerine ve kiliselerine saygı gösterileceğini ve Müslümanların Hristiyan kiliselerinde namaz kılabileceklerini bildirdi. Amr'ın Mısır'daki davranışları daha az iyiliksever olmamıştır. O, halka tam bir dinsel özgürlük, herkes için tarafsız bir adalet, mülklerin dokunulmazlığı ve Yunan imparatorlarının aşırı vergilerinin yıllık bir haraçla değiştirilmesi önerisinde bulundu. 
şadığı söylenir. Kendisiyle yukarıdaki düşünceleri paylaştığımda, şöyle dedi: "En adil ve en kolay çözüm, vaktiyle bizim halifelerin Kitap Ehli’ne - onları hükümdara gerçek bir bağlllık karşıllğında, iç hukuklarına göre özyönetime sahip cemaatler halinde yapılandırarak- yaptıklarını, sizin hükümetlerinizin de, bize uygulamaları olmayacak mıdır? Bu sizi birçok karmaşalardan ve kargaşalardan kurtaracaktır, bize ise sayısız sorunlar getirecektir”.

Şeyhe karşı, cumhuriyetimizin bölünmezliği ve laikliği benimsediğini ve farklılıklar hakkında yasak getirmemesinin şartının da bu olduğunu savunmakta bayağı zorlanıyorum. O aslında, bana karşı, bugün, bu farklılıkların çoğunun ayrı yaşam alanlarında sıkışıp kaldığını savunuyor. Ve Amerika Birleşik Devletleri'nde, hatta İngiltere'de, işler çok daha ileriye, ayrımcılı̆̆a kadar gidiyor.

Ona dedim ki, "burada sorunun sadece mantıkî bir sonucu söz konusudur. Temeli oluşturan şey, ne mahallenin ne de eşkâlin farklılı̆̆ıdır, fakat ortak referansın/kaynağın yokluğudur. Netice itibariyle, bir dalgıç kıyafeti içinde mi yaşanmalı, yoksa işin-özü için, aynı değerlere mi sahip olmalı?”

-“Ama işin-özü nedir?” diye sordu bana gülümseyerek.

Önümüze konulan ikilem, İslam»ın Avrupa`da ve her iki Amerikarda tasarladığı pek çok azınlık için yapmak zorunda olduğu yakıcı seçim ikilemi, hala devam etmektedir: ya bir 'dalgı̧̣ giysisi içinde yaşamak' ya da kabul ortamına uygun evrimleri icat etmek.

İslam, tamamen mirasın güncellenmesinin din bilimine olduğu kadar Ötekinin ve Başka-Yerin din bilimine de gerek duymayacak mıdır?

Hukukta uzay ve tarih... Eğger, günümüzde şari’a, “Kanun”, ya da Sunna, "Sistem" olarak adlandırılan kurucu büyük hukuk ekollerinin/mezheplerinin olgunlaşması, Miladi 9. yüzyılın sonuna tarihleniyorsa, şu tespitler göz ardı edilemez:

Vaktiyle İslam, iki yüz yıllık bir gelişme dönemi yaşamıştı: Fıkhî/ç̧tihadî deneme, kuram araştırması ve siyasî tecrübe, en sonunda Maveraünnehir'den ${ }^{51}$ Endülüs'e kadar yayılmıştı. Bu tür büyük hâdiseler, başlangıç kêrugma’sı olgusunun gelişmesi üzerinde etkili olmayacak mıdır? [Grekçe olan kêrugma, müjdeciden bildirge, iyi haberin ilanı demektir]. Daha sonraki tarih, bugüne kadar, yorumlamada ve uygulamada nasıl göz ardı edilebilecektir?

51 Maveraünnehir/Transoxiane, Aral Denizi'nden güneydoğuya doğru Hindu-Kuş'un eteklerine uzanan, Semerkant ve Buhara kentlerini de içine alan bir Asya bölgesine verilen isim. 
İslam insanının macerası, Araplar, Türkler, Persler ve diğerlerinin tarihinin yeni iniş çıkışlarıyla birlikte eşi görülmemiş bir yola girmektedir. İslam artık, kendisi için sadece girmiş olduğu bir Darül-Harb ya da "Savaş Alanı"ndan kurtulabilen topraklar üzerindeki diğer dinler ve kültürler ile değil, fakat ciddi hayal kırıklıklarının acısıyla bütünleşmek zorunda olduğu sahil sistemleri ya da uluslararası bir birlik ile de kesişmektedir. Konumların, yaşam çevresinin, sorunların süratle yenilenmesine bağlı olan bu halin, kendi durumları üzerinde, muayyen bir seviyeye kadar, yankı uyandırmaması mümkün değildir.

İlkelerin projeksiyonu/izdüşümü içinde, yeni çözümler: bu çağımızın içtihadı olacaktır. Çok erken kaybedilen, İranlı düşünür Şeriati'ye ${ }^{52}$ borçlu olduğumuz çok açık bir gözlem vardır ki o da şudur: Birçok aktivistin bugün ısrarla istediği şari'a, onları fiksizme/saptanımcilığa değil, fakat aksine, kelimenin kök anlamının gerektirdiği dinamiğe bağımlı kılmaktadır. Şari’a, gerçekten, yolu, çıkışı, yol almayı hatırlatıyor.

Ayraç V (veya Doğal Sonuç). Müctehid şu sonuca ulaşabileceğine inanıyor: "Klasik mirasın yeniden okunmasında verimli bir araştırmanın yönetiminin, artık bütün akademizmlerde ortak olan öz-tatmin duygusu üzerine değil fakat aksine, bu mirasın zayıf noktaları ve çıkmazları üzerine kurulması gerekir”.

Ben ise, onu dinlerken aklımdan sapkın sorular geçiriyordum: "Neden İbn Rüşd'ün, İbn Haldun'un ${ }^{53}$, ya da daha yakınlarda Şah Veliyullah Dehlevi'nin $(1703-1762)^{54}$ veya İkbal'inki gibi son derece verimli düşünceler takipçilerini bulamamışlardır? Neden kısacası sonuca ulaşamamışlardır?

Müctehid, en önemli noktayı unuttunuz diye 1srar etti: Neden gelenekçiler ve yorumcular, Kur'an'da çok geçen rasyonaliteye/ussallığa çağriları geleceğe taşıyamamışlardır? Neden filozoflar, ve sizin yukarıda öncelikle bahsettiğiniz İbn Rüş, Kur'an'dan ziyade Grekleri yorumlamışlardır? Bu Felasife'lerin [Helenistik Arap filozoflarının] hiçbirinin, buna cesaret edemediği bir vakıadır. Onlardan biri tarafından yapılmış bir Tefsir'in [Kur'ân yorumunun] bizim nazarımızda kazanacağı değeri bir düşününüz!

\footnotetext{
52 Alî Şeriati (1933-1977): Şii İlahiyatçı, İranl1, Meşhed'de doğdu. Fransa'daki incelemeleri ona güçlü bir bakış açısı kazandırdı ki buradan hareketle İslam doktrininin yeniden canlandırılmasını denedi: el-'Avda ile'z-zat [Kimliğe Dönüs] adlı eseri 1981'de Arapça'dan Fransızca'ya tercüme edilmiştir ve Histoire et Destinée (Tarih ve kader) adlı başka bir eseri vardır (Fransızca seçilmiş metinler), 1982.

53 İbn Haldun (1332-1406): Tarihçi ve Maghripli düşünür. Anıtsal bir Berber tarihinin yazarıdır ki bu eserin Mukaddimesi, tarihin ilk sosyolojisini ortaya koymaktadır. Onu takip eden talebeleri olmamıştır. Çok daha sonra, şüphesiz, Oryantalizm'in etkisi ile şöhrete kavuşmuştur.

54 Şah Veliyyullah Dehlevî (1703-1762): Hintli ilahiyatçı. Kur'an'1 Farsça'ya çevirdi. Mükemmel bir şer'î müceddid olan Dehlevî, muazzam bir eser bıraktı: Huccetu'l-Allahü l-Bâliga [Tanrı'nın mükemmel belgesi] ve diğer birçok el-kitabı vardır.
} 


\section{Gelecek: Kendi Öz Hakikatini Dünyanın Gelişmesi İle Uzlaştıran Bir İlerleme İslam'1}

IV. KAPSAMLI BAKIŞ. Lakin biz, Batı tarihinin yıkımlardan, yok oluşlardan ve çıkmazlardan o kadar masun olduğundan emin miyiz? Diğer medeniyetleri incelediğimiz zaman, hala pek çok çalışmayı yıkıp yok eden örosantrizmden /Avrupa merkezciliğinden sakınalım.

Netice itibariyle, İslam nasıl görülmelidir?

İslam takipçilerinin birçoğu, Batı'dan gelen 1şıklara/bilgilere sarılmışlardır ki, onları haklı ya da haksız olarak kendi öz miraslarına yakın görmektedirler. Zaten, yaşam ortamı tahavvül edip duruyordu. Müslüman halklar diğgerleriyle birlikte dünyanın tekdüzeliğine doğru sürüklendiler. Lakin tutumlarının büyük bir kısmının, çok az dönüşüme uğramış olduğu anlaşılmaktadır. Sadakat ya da atalet, taklitçiliğe ya da tersine çevrilmiş kültürleşmeye karşı direnç, hem iç cazibeye hem de dış baskılara karşı koyacaktır. Böyle bir savunmada, kimlik hakkı iddiasının gücü hem silah hem de simgedir.

Bu genel bağlam içinde, İslam, bir din olarak, kendi öz sorunlarına meydan okumak zorundadır. Bu sorunları ele almak için hatta onları dile getirmek için bile, İmparatorlukların sonunu takip eden sömürgeciliğin bozulmasından yararlanamamıştır. Onların tedavisi, siyaset yöneticileri için çok fazla risk taşımış olmalıdır ve ulemanın [İslam âlimleri] pek uygun olmayan yorumları da... Her ikisi de, bu görevden uzak durdular, tıpkı onlardan önce, farklı sebeplerle, önceki rejimin yapmı̧ olduğu gibi...

Zamanla ve siyasî hayal kırıklıklarının çoğalmasıyla, İslam, inananlarının ekseriyeti nazarında, yabancının komplosuna, rejimlerin başarısızlığına ve insanların kötülüğüne karşı bir sığınak olarak kabul edilmektedir. İşte bu rol, pek çoğunun gözünde, manevî role galebe çalma raddesine gelmişti, ancak biriyle diğeri arasında en zorlu eş anlamlılık devam etmektedir. Bu raddeye, hafif olsa bile herhangi bir saldırıy, herhangi bir eylemi, herhangi bir ifadeyi, egemen simgeyi zedeleyebilecek herhangi bir eleştiriyi yasaklamak için gelinmiştir. Demokrasinin mahkûm edilmesine bir adım kalması buradan kaynaklanmaktadır. Bazı gruplar bu eşiği de aşmaktadırlar. Bunlar, sırf kendilerinin yüklenmek zorunda oldukları hoşgörüsüzlük ve obskürantiz $m^{55}$ töhmetlerini, toptan Müslüman toplumu üzerine sıçratmaktadırlar.

55 Egemen güçlerin kendi hoş görmediği kavramlara, kişilere, topluluklara ilişkin toplumun bilgi erişimini sistematik olarak kısıtlama çabası (TDK, BY). 
Hiçbir aydın Müslüman, hiçbir İslam dostu, en saygıdeğer bir Kanun'a, bir kültüre ve tarihe karşı haksız ve yanlış benzer alaşımlardan mutlu olmayacaktır. Bununla birlikte, bu yirminci yüzyılın sonunda, bu büyük din, ne kitlelerin güvenini, ne de meşru bir şekilde yararlanabileceği dinamizmi harekete geçirecek kendine özgü ayarlar bulmuş gibi gözükmemektedir. Kendi hakikati ve etrafındaki dünyanın inkişafı arasındaki en büyük ortak böleni İslam'a sunmaya muktedir olan tek şey, şüphesiz sadece bir ilerleme İslam'ının olgunlaştırilmasidir ${ }^{56}$.

\section{///}

\section{Seçilmiş Bibliyografya:}

Berque, Jacques (1980), L'Islam au défi, Paris: Gallimard.

Berque, Jacques (1995), Le Coran, essai de traduction, Paris: Albin Michel.

Burgat, François (1988), L'islamisme au Maghreb, la voie du Sud, Paris: Karthala.

Chérif, Mustapha (1990), Culture et politique au Maghreb, Alger: Maghreb224 Relation, Sd.

Gardet, Louis (1982), Lislam, religion et communauté, Paris, Desclée de Brouwer.

"Hilaf Allah (1992), “Hakku'1-İhtilâf fîl-mefhûmi'l-İslâmî” [İslami tasarımda ayrışma hakkı], el-Kâhira Dergisi, Kahire,1992.

Malek, Rédha (1993), Tradition et révolution, l'enjeu de la modernité en Algérie et dans l'Islam, Paris: Sindbad,

Sellam, Sadek (1990), Etre musulman aujourd'hui, Paris, Nouvelle Cité, Rencontres.

Talbî, Mohamed ve Dr. Bucaille (1989), Réflexions sur le Coran, Paris, Seghers.

56 “Olgunlaştırılma” diye çevirdiğimiz kelimenin Fransızcası, "élaboration”dur. Bu sözcük, canlı bir organizmada bir özün/cevherin oluşumu; uzun bir entelektüel çalışmayla yaratma eylemi demektir. Önemli bir kavramdır. "Olgunlaştırma” zihinde aynı anlamı çağrıştırmıyor. Daha iyi bir kelime bulmak gerekir. Aslında Arapça "ictihad” kelimesinin bu işleve sahip olduğunu düşünüyorum (BY). 